\title{
Comparative Analyses of Strategic Financial Management Practices In Faith-Based and Community-Interest Organisations
}

\author{
Oladeji Tolulope Femi, Oyewo Babajide Michael and Akinjare Victoria Abosede
}

School of Business, Department of Banking and Finance, Covenant University, Ogun State, Nigeria

Correspondence should be addressed to: Oladeji Tolulope Femi;

tolulope.oladeji@covenantuniversity.edu.ng

Received date: 19 August 2014; Accepted date: 7 November 2014;

Published date: 20 September 2016

Copyright (C) 2016. Oladeji Tolulope Femi, Oyewo Babajide Michael and Akinjare Victoria Abosede. Distributed under Creative Commons CC-BY 4.0

\begin{abstract}
Non-profit organisations render certain services not provided by business or public sectors such as skills development, employment creation and fostering of pathways for social inclusion. In spite of their generally-acknowledged significant contribution to the society, researches on the management of their finance are not much. This research therefore advances the frontiers of knowledge by comparatively analysing the financial management practices of two non-profit organisations; a faith-based and a community-interest organisation. The research adopted a field-based approach by evaluating the financial management practices of study organisations using methods such as interviews, study of documents, artefacts and published annual reports. The research found out that though the two organisations are fully aware of the risks involved in the management of finance, different strategies are adopted to mitigate the risks. Though not established for commercial purposes, Non-Profit organisations are encouraged to embark on cost control and reduction to justify their funding by financiers
\end{abstract}

Keywords: Financial Management Practice, Liquidity, Non-profit organisation, Strategic Financial Management

\section{Introduction}

The contribution of non-profit organisations to the community is widely acknowledged as the provision of goods and services that are not delivered by the business or public sectors, such as skills development, employment creation and fostering of pathways for social inclusion (Weerawardena et al, 2009). Different acronyms like community based organisations (CBO), voluntary organisation, nongovernmental organisations (NGO) and not for profits (NFP) etc.are used interchangeably to refer to non-profit organisations. In the light of this study, the

Cite this Article as: Oladeji Tolulope Femi, Oyewo Babajide Michael and Akinjare Victoria Abosede (2016)," Comparative Analyses of Strategic Financial Management Practices In Faith-Based and Community-Interest Organisations", Journal of Financial Studies \& Research, Vol. 2016 (2016), Article ID 381395, DOI: 10.5171/2016.381395 
acronym non-profit organisation (NPO) will be used frequently.

A non-profit organisation (NPO) is a private corporation that works for the public's benefit, but it is separate and independent from the government (Gulati-Partee, 2001). It is controlled by a board of trustees who do not have economic interests in the firm. The goals of a non-profit organisation are outlined in the firm's mission statement. NPOs receive contributions from significant resource provider who do not expect a commensurate or proportionate monetary return.

A community interest company (CIC) is a business with primarily social objectives whose surpluses are principally reinvested for that purpose in the business or in the community, rather than being driven by the need to maximise profit for shareholders and owners. CICs tackle a wide range of social and environmental issues and operate in all parts of the economy.

NPOs are often faced with increasing agenda of activities that requires funds to be spent in order for the organisation to fulfil its mission (Lightbody, 2000). This calls for a need for proper planning and control of the available financial resources as these organisations have limited opportunities for generating extra income.

The objective of the research is to examine the roles which strategic financial management plays in NPO especially religious charity as well as their comparative roles.

This study aims to contribute to the current research on financial management in nonprofit organisations as the existing research on the subject is sparse owing to lack of data. This study is particularly important as a preliminary literature review has revealed that there is little research on the topic in general and no significant number of direct researches relating to the topic has been performed on faith based organisations ${ }^{1}$ (as far as the researchers are aware).

1 The word faith- based organisation used herein refers to a church

\section{Literature Review}

\section{The concept of Financial Management}

Financial management is concerned with how a governmental unit or agency employs the means to obtain and allocate resources or money as well as utilisation of methods and control to effectively achieve publicly determined ends (McKinney, 2004). Moreover, Kautz (2007) is of the view that financial management is the process of managing the financial resources, including budgeting/costing, accounting and financial reporting and risk management. It is impossible for an organisation to survive without proper financial management (Maritz, 2005). Budgeting and cash management are two important areas of financial management in NPOs (Blackbaud, 2004). It is therefore important for the organisation to pay close attention to whether it has cash reserves that will be enough to continue to provide service to its clientele. Financial management processes of NPOs are generally dominated by conditions of resources scarcity (Lightbody, 2000).

Zietlow et al, (2007) submitted that corporate financial theory is well developed for business but it is still in the earliest stage of development for non-profit organisations (NPO). As such, the only broad range financial theory of NPOs was developed over two decades by Richard Wacht. Wacht advocates a cash flow balancing approach to non-profit financial management. He states that the financial manager must ensure that the actual cash inflow and outflow are balanced and the operations are proceeding according to plans. He recommended that NPOs should minimise cost in order to maintain organisational liquidity and solvency over time.

\section{Liquidity Management}

Wacht recognised the importance of liquidity along with cost control and he was found to be the only one to ever devise a full-blown model of how mission and finance may work together in a non-profit organisation. However, argument raised by 
Zietlow et al., (2007) suggest that it is unclear on how non-profit should minimise cost: new project implementation or existing program expansion can prevent the organisation from meeting its financial goals of liquidity and solvency, and plunge the organisation into a financial crisis.

Richard's framework reveals the ability of an organisation to develop and correctly use a fairly detailed financial model. It is quite difficult for a financial manager to back or reject proposed capital projects or program expansion initiatives without a model like that. Zietlow et al, (2007) suggested that liquidity management should be more proactive than reactive and organisations are advised to start liquidity planning right from the start-up of the organisation.

Another argument raised by Zietlow et al, (2007) on the model is that Wacht overlooks the cash position and short term securities components of an organisation's liquid reserve. Their argument is that financial uncertainties must be dealt with by ensuring that sufficient flexibility is built into the budgets and financing arrangements to avoid jeopardising the organisation's solvency.

Despite the objection raised by Zietlow et al., (2007) on Richard Wacht theory on liquidity management, it still fit into focus of the study. This is as a result of its cash flow balancing approach to ensure that the NPO minimises its cost so as to maintain liquidity and solvency. However, the author agrees with the suggestion of Zietlow et al., that liquidity management should be more proactive than reactive. Since the focus of the study is not particularly on liquidity management or to test any theory, an alternative research instrument will be used.

\section{Cash Management}

Cash management is a subset of treasury management and it involves the collection, mobilization and disbursement of cash within a business enterprise (Zietlow et al., 2007). The effect of cash flow is real, immediate and should not be mismanaged (Allott, 2001). A sound cash management causes improvement to process and service delivery of business even though it can be extremely difficult to predict especially in NPOs as they rely on revenue from resource providers that do not expect to receive the service provided (Blackbaud, 2004). However, it is vital to note that where cash flow is not properly managed, it can result into the downfall of the organisation (Allott, 2001).

Dropkin and Hayden (2001) is of the view that an effective cash management is vital to NPOs as it is a key element in planning and in the efficient functioning of all aspects of the operations. However when cash inflow and outflows are not successfully monitored and planned, organisations may find it difficult to pay employees and vendors in a timely manner. Hence, without a good cash flow management, an organisation may be profitable based on its financial statements yet unable to pay bills when they are due.

In another research carried out by Batrancea et al (2008), they are of the opinion that cash flows are used for determining the liquidity lacks of an entity. They established that the financial viability and the future survival of any organisation consist of its capacity to be able to generate a positive cash flow. Cash flow was also found to aid reduction in the dependence of the organisation on external funds. It also helps the fulfilment of the duty service and liabilities, accomplishment of financial investments and offering investor an acceptable dividend policy. However irrespective of the profit reported, if the organisation is not able to generate enough cash, it will go bankrupt (Chastain and Cianciolo, 1986). Batrancea et al., (2008) suggested that the best method to assess the success of a business is when cash inflow is higher than outflows.

Using telephone interviews and questionnaires, Jose et al., (2008) carried out a research on cash management and treasury management. Based on the firms that were used for the research, it was found that firms have a positive view of the most important responsibilities of cash management. Besides, the firms 
interviewed stressed the importance of monitoring and optimising the sales-cash circuit as well as drawing up of short term treasury forecasts, at least monthly. Their research confirmed the prevailing views in literature that organisations see all the responsibilities of cash management as highly important.

\section{Financial Planning}

According to Gunderson (2008), planning is a common denominator in every successful non-profit organisation. A budget is a financial plan that serves as a guide for monthly operations of an organisation. It is considered to be one of the most important management tools that can be used to steer the organisation, evaluate its performance and motivate its people (Waal, 2005) However, it is one of the most critiqued accounting practices in business. (Sivabalan and Brown, 2008).

Hartnett (2009) examined the role of budgeting in non-profit organisations and it was found that every NPO no matter what their size should have a prepared budget that can act as planning mechanism, or road map to keep the group focused on achieving its mission. The author noted that the budgeting process should not be seen as a painful experience to be avoided or delayed at all costs but rather as a way to proactively prepare and plan for the coming year in order to ensure that the organisation's mission will be met.

However, Neely et al., (2003) stressed that budgeting could be counterproductive as it is usually affected by gaming, corporate politics and horse trading tactics. Moreover their study revealed that many organisations that they researched on still have a long way before their efforts will allow them to let go off the reins of budgeting malpractice. Kluvers (2001) carried out an exploratory research on budgeting. Using questionnaires to gather data, the author attempted to answer questions relating to budgeting in catholic parishes. It was found that forecasting in an organisation is apparent but in limited way and that budgeting is generally of secondary importance in the running of the church at the local level. Moreover, the author's findings suggested that the parish accountant is involved to a large extent in the budgetary process but has not reduced the resistance to budgeting.

Irvine (2005) in another research, examined budgeting practices and attitudes in a local church. This was done through the use of semi structured interviews with the key church leaders over a six month period and studied financial reports as well as the minutes of church meetings. Irvin found that the budget was used as a surrogate for the spiritual goals of the church, to objectify, legitimate and justify certain actions, and to monitor the success and accountability of the church in achieving its stated goals. He raised the point that if the organisations are not able to account for the resources they need for their mission, their ability to fulfil that mission is likely to be compromised.

\section{Cost Benefit analysis (CBA)}

Cost benefit analysis is used to assess the total anticipated cost of a project compared to the total expected benefits in order to determine whether the proposed implementation is worthwhile for a company or project team (Smith, 2010). Cost benefit analysis (CBA) is the most widely used quantitative approach among several approaches that is used (Mustafa, 1994).

Moreover, CBA can enable an organisation to prudently use their budget to gain more credibility from various stakeholders (Linn, 2009). In support of that, Noy (1999) is of the opinion that cost benefit will help managers to decide which control system requires improvement. Though CBA involves investment of time and effort, the information that can be gained from a good quality CBA can provide significant pay backs through improvement in the quality of decision as well as boosting the confidence of the organisation (Davies, 2000).

\section{Analysing Financial Performances}

Financial ratio can be seen as an important 
tool in analysing an organisation's financial health as they are arithmetic computations that are easy to use for both internal and external reporting (Peer, 2008). The financial ratios are very useful in identifying the trends with the organisation's own financial statements (Peer, 2008).

Abraham (2006) carried out a research on ratio analysis and he found that financial ratio analysis formalises and quantifies financial data to facilitate comparison within an organisation. Also it was discovered that ratio analysis provides an efficient means by which financial data can be reduced to a more understandable basis for evaluation of financial condition and operating performance. Moreover, the measurement of financial performance through ratio analysis helps to identify organisational strengths and weaknesses by detecting financial anomalies and focusing attention on issues of organisational importance. It was concluded that issues that affect an organisation will not always be financial but will be directly related to the culture and traditions of the organisation as mission is at the central heart of every NPO.

\section{Research Methodology}

\section{The Research Approach}

There are two main research approaches, namely deductive and inductive approach. The choice between the deductive or inductive research approaches has been discussed by a number of authors (Saunders et al., 2007; Hussey and Hussey, 1997; Collis and Hussey 2009).

Deductive approach involves the development of a theory that is subjected to rigorous test (Saunders et al, 2007). The deductive method is referred to as moving from the general to the particular. Inductive is a study in which theory is developed from the observation of empirical reality. As a result, general inferences are induced from particular instances, which is the opposite of the deductive method as it involves moving from individual observation to statements of general patterns or laws (Hussey and Hussey 1997).
The possibility of using both inductive and deductive approaches in the same study has been discussed by different authors (Saunders et al, 2007; Perry, 2001; Cavaye, 1996).

The researchers do not intend to develop or test any theory as an alternative research instrument will be used. More so certain features of the deductive approach like collection of quantitative data makes the approach qualified for use in this study. Therefore, in this study, the two approaches were used because of the nature of the research work as both qualitative and quantitative data were used to solve the research questions and the objectives.

Given the nature of the research problem and the stated objectives, the case study alternative was found to be the most appropriate for this study. In essence, case study approach is appropriate because it is a research strategy that focuses on understanding the dynamics present within single settings (Eisenhardt 1989).

\section{Method of Data collection}

The research adopted a field-based research approach on the two non-profit organisations by evaluating their financial management practices using the following methods to generate data:

Interviews: The structured and the semi structured interview method were used based on some questions that centre on the research topic

Documents and Artefacts: The documentary source for data collection for this study included: Annual financial report of the church downloaded free from the charity commission website and annual financial report of the charity company purchased from the company house website.

\section{Population and sample of study}

The participants involved in this study were selected based on their relevance to the conceptual questions rather than their representativeness. The participant's job breakdown was also selected based on their relevance to the study. Considering the 
nature of the research, the purposive sampling method was selected as the most appropriate. Powell (1997) firmly supports the purposive sample as it may seem preferable to select a sample based entirely on one's knowledge of the population and the objectives of the research

\section{Background information of study organizations}

Two non-profit organisations - one faithbased and one community-interest organisation, both based in the United Kingdom- were selected for the study and the case study approach was used. The selection of the two organisations as the primary focus of study is based on access to and availability of data.

The church has a vibrant student led youth fellowship in more than ten universities in the United Kingdom. The church is registered as a single body with a network of branches. It submits only one annual report at the end of each financial year. Its main focus is to empower lives by building the society. They do this through the advancement of the Christian religion in England and Wales; relief of poverty to general public and mankind; providing education and training for youths and the less privileged within the local community. It is governed by a board of trustees whose members are elected at the annual general meeting and are trustees for the purposes of charity law.

As a centralised structure, the church branches are headed by five different pastors who have little or no power on how the offering/donations raised at their branches are disbursed. They have to contact the headquarters to approve the release of funds to run activities in their branches as they are volunteers. It is only the headquarters that has salaried staff who execute most of the tasks on behalf of the church branches. The church as a corporate parent provides value adding activities to its branches. The charity organisation finances its projects through offerings/donations from donors and partners who give to them. They are also able to reclaim from the Inland Revenue, a certain percentage of the donor's funds, especially those of tax payers through the gift aid scheme. The gift aid is basically a tax relief that is allowed on any money that is donated to UK charities. On average over the past three years, the Church has been reporting an annual income of $£ 375,014$ as well as an expenditure average of $£ 404,241$. Most of the funds realised by the church are spent on youth empowerment programmes as a large percentage of the congregation are principally youths/university students who are still dependants on their parents/next of kin. Apart from youth, they also have adults as part of the congregation.

The second study organisation is a community interest company (CIC) designed for social enterprise that uses its profit and assets for the good of the public, supported by community foundation, Community Development Fund (CDF) and donations from private individuals.

A community interest company (CIC) is a new type of company introduced by the United Kingdom government in 2005 under the Companies (Audit, Investigations and Community Enterprise) Act 2004, working for the benefit of the community. The company is aimed at bringing people together for economic development and social gain as well as facilitating empowerment of lives and societal building through training, counselling and sharing information. The overall management of the company is the responsibility of the directors who are elected and co-opted under the terms of the memorandum of articles and association. The finance director is vested with the power to execute the finance decisions made by the team. The day to day activity is managed and carried out by project coordinator and volunteers. The company finances its project through grants received from the business support organisations and the government. As a social enterprise, all the surpluses made by the organisation, are either reinvested back into the business or used for the community benefit. Over a three year period, the CIC received an annual average income of $€ 7,107$ and expenditure average amounts to $£ 4,131$. 


\section{Presentation and Analysis Of Data}

\section{Faith-based organisation Interview Analysis}

In order to address the objective of examining cash management and budgeting as well as the associated risks, a semistructured interview of the finance manager of the church was first done. Below is a summary of the outcomes by theme of what transpired in the interview.

\section{Theme 1: Cash management}

The finance manager pointed at cash and cheques donations from members of the church and friends of the ministry as being the sources of funding for the organisation. Friends of the ministry according to her are those who are not members of the church but who believe in the cause that they are pursuing as a church. These donations are either given to them on a weekly basis during a Sunday service or in the course of the week through the post or via the phone through card payments. A combination of adults and youths are the bulk of donors for the church. The manager also made it clear that the record of cash and cheques they receive are reconciled to actual cash lodged at the bank on a weekly basis even though it is more or less done on a daily basis. This they do being mindful of how irregular reconciliation of bank accounts could affect the flow of cash and payments to customers in a timely manner. They also ensure that disbursements are properly documented with evidence of receipts of goods or services. The author was finally made to understand that there is a financial policy in place to guide their financial decisions and it is reviewed every three years.

\section{Theme 2: Cash Management and the Associated Risks}

The finance manager explained that risk of theft, misappropriation of funds and poor reconciliations are the risks involved in the management of cash in the church. The manager also explained that rescheduling of payments and negotiation with customers are the coping strategies that they have adopted in order to cope with financial risk associated with unavailability of funds and the like. Moreover, it was pointed out that reduction of programme or outright cancellations are the strategies they utilise to cope with income irregularities associated with having a large youth congregation. As their absence during vacation periods affects the cash flow. The finance manager opined that the organisation has provision to save parts of its income in a reserve account during periods of windfall as they are not into trading and the charity money cannot be invested. Moreover, as a way of safeguarding the charity's fixed assets to avoid unnecessary spending, there are insurance policies in place for all the assets. Finally, the financial manager submitted that having proper financial control is important to them as it will help the donors to continue to trust and support them.

\section{Theme 3: Budgeting}

According to the finance manager, planning for programmes is done through the conference planning committee (CPC). The CPC meet to discuss the logistics, fundraising and how a programme will be handled few months to it. The manager also explained that financial solvency is the most important factor they consider whenever they are planning for programmes. It was also stated that if the organisation is not solvent enough to handle the programme; they either scale it down or cancel it completely. More so, the target audience is also another factor they consider - youth programmes are put on hold when students are on vacation. The manager explained that the Church has a comprehensive annual budget at the start of the financial year which is prepared by a group of people. The budget is not followed through because so many variables like inflation rate, interest rate and the valued added tax (VAT) affect the implementation of budget in the cause of the year. If the budget was followed through and a specific sum of money has been earmarked to cater for the items on the budget, in a situation of inflationary increase, VAT increase and other demands in the system, the money might not be sufficient. In a situation like that, the cash flow will be affected as it is 
not possible to put too much pressure on the donors who have given out of free will.

Budgeting was said to affect the availability of funds for programmes because if a programme that is not included on the budget comes up, it will affect the release of funds for such a programme as well as other programmes already budgeted for. Finally the finance manager stressed that the mission of the church is always an undertone when considering planning for their programmes.

\section{Community-Interest Company Interview Analysis}

In order to have a robust examination of the role which cash management and budgeting playing relation to financial management, a semi-structured interview of the finance director of the CIC was also done. Below is a summary of the outcomes by theme of what was revealed at the interview:

\section{Theme 1: Cash management}

The finance director made it clear that the source of funds for the organisation is grant and the frequency of these grants depends on availability of funds as well as eligibility to apply. As they only apply for funds that relates to their objective as a company. But averagely they are able to get grants about two times in a year. He further noted that these grants are obtained from the government who is their major donor. The director also made it clear that because most of the funds they get have strict regulations, when the money comes in the form of cheque, it is lodged at the bank. He further opined that, part of the condition of most grants is for them to precisely state what the money will be used for. Thus they have to ensure they reconcile the cheques given to actual cash lodged at the bank. Moreover, they carry out a reconciliation of their bank accounts regularly to ensure that no transaction is carried out that can affect any designated fund that has been given to them. Also, all disbursement of funds is properly documented with evidence of receipts as no expenses are allowed outside what is already stated in the proposal. Finally the finance director explained that the article of association contains their financial policy and they adhere to it but it has not been reviewed since the inception of the company.

\section{Theme 2: Cash Management and the} Associated Risks

The finance director pointed that the risk that they have experienced in the management of cash is inflation and funders requesting a refund on items not included in a proposal. This happens because of the length of time it takes before they are able to get grants for proposed projects. The director noted that the Company have been able to cope to a certain extent with financial risk associated with rise in price or unavailability of funds as they "fly on the wings" of a faith-based organisation. It was however admitted that it has been very difficult recently to get grants as little money is made available following the recent cuts in the economy. This has made it difficult for them to embark on projects they would have loved to. Moreover, he stated that because they have a good standing with their funders, they have been able to cope well with income irregularities associated with their source of funding. On the issue of saving, the researchers were made to understand that the organisation does not have any provision for savings as a result of the strict conditions attached to most of their funding. They are looking for alternative ways of raising money for the future though. Finally, the director is of the opinion that internal financial control is vital to the company as lack of control could enlist them in the bad books of funders or even prosecution.

\section{Theme 3: Budgeting}

According to the finance director, planning for programmes depends on the kind of funds they are able to get. Their plans for any proposed project is already incorporated in the proposal that they submit for grants. Also, he stated that the main deciding factor for embarking on projects is availability of funding. Moreover, the organisation does not have any comprehensive annual budget as they can only plan when they get funds/when they 
want to submit a proposal for grants. Finally, the director believes that budgeting can affect availability of funds for programme if the company had the chance to budget ahead of time and try to solicit support from other nongovernmental sources. They could be better off.

\section{Financial Analyses}

The financial performances of the two organisations were analysed using quantitative data that was collected from the published annual report of the both organisations covering three financial years (2007 -2009). Some selected ratios were estimated for both organisation and the results were analysed. The results obtained are presented in table 1

\section{Table1: Financial Performance of Faith-based Organisation}

\begin{tabular}{|l|l|l|l|l|}
\hline Measures & Ratios & $\mathbf{2 0 0 7}$ & $\mathbf{2 0 0 8}$ & $\mathbf{2 0 0 9}$ \\
\hline \multirow{5}{*}{ Liquidity } & Current Ratio & 0.038 & 0.024 & 0.036 \\
\cline { 2 - 5 } & Quick Ratio & -1.1 & -1.33 & -1.71 \\
\cline { 2 - 5 } & Net working Capital & -587909 & -571578 & -432951 \\
\hline Debt structure & Debt-Equity & 0.96 & 0.98 & 0.97 \\
\hline Sources of Fund & Source of fund (donation and gift) & 0.74 & 1.02 & 1.01 \\
\hline Uses of fund & $\begin{array}{l}\text { Use of fund 1 (direct charitable } \\
\text { expenditure) }\end{array}$ & 0.7 & 0.69 & 0.33 \\
\cline { 2 - 5 } & Use of fund 2 (administrative expenses) & 0.3 & 0.31 & 0.66 \\
\hline Net operating & Net Operating & 0.735 & 1.02 & 1 \\
\hline
\end{tabular}

Analysis for the faith-based organisation (see table 1 above for ratio computation for year2007 to 2009)

Liquidity: The current ratio for the 2007 financial year was at its highest value of 0.038 in 2007. This value however fell by $1.4 \%$ in 2008 to 0.024 .Though, in 2009 , the current ratio peaked at 0.036 suggesting a rise to $1.2 \%$. For the period under study, the current ratio suggests some signs of cash flow problems. To gauge this problem, a more severe test was carried out using the quick ratio. As was seen with the current ratios, the quick ratio for the 2007 financial year was the highest at -1.1 while the quick ratio for 2008 and 2009 financial year stood at -1.33 and 1.77 respectively. Moreover, the net working capital for the three year period followed a similar trend like the quick ratios with negatively descending values. Following the liquidity measure, it is obvious that church is experiencing some cash flow problems as it has not been able effectively meet its short term obligation.

Debt structure: As measured by the debtequity ratio, the debt structure showed relatively high values for the three year period under study with the highest value of 0.98 coming up in 2008 and the lowest value of 0.96 in 2007. This is a total deviation from what was deduced from the liquidity measure.

Sources of funds: this measure shows that the Church was too dependent on donations and gifts from voluntary donors (at 0.74 of total expenditures in 2007). Moreover, a rise in the organisation's rate of reliance by $28 \%$ in 2008 further supports this. Even a $1 \%$ drop to 1.01of total expenditure in 2009 did not prove otherwise. Though the measure reveals that the organisation is heavily dependent on donation and gifts, this might be as a result of significant improvement in donations and gifts over the three year period. 
Uses of funds: this measure reveals that $70 \%$ of the total expenditure was committed to direct charitable expenditure in 2007. This is immediately followed by a $1 \%$ fall in 2008 and a further dip to $33 \%$ of the total expenditure in 2009 . On the other hand, $30 \%$ of total expenditure was committed to administrative expenses in 2007. This figure rose to $31 \%$ in 2008 followed by a $35 \%$ growth in 2009. Over the three year period, uses of funds revealed that the administrative expenses are receiving more attention at the cost of direct charitable expenditure. This might be as a result of the organisation's debt obligations, salaries and bank charges.

Net operating results: this measure revealed a deficit at 0.74 in 2007 suggesting that the total expenditure for that year exceeded the total revenue. However the situation changed in 2008 and 2009 when there was a surplus at 1.02 and 1.00 respectively. The organisation had more income compared to the expenditure

Analysis for the Community-Interest Company

(The result obtained for ratio computation is presented in table 2 below)

Table 2: Financial performance of Community Interest Company

\begin{tabular}{|l|l|l|l|l|}
\hline Measures & Ratios & $\mathbf{2 0 0 7}$ & $\mathbf{2 0 0 8}$ & $\mathbf{2 0 0 9}$ \\
\hline \multirow{4}{*}{ Liquidity } & Current Ratio & 0 & 3.74 & 15.4 \\
\cline { 2 - 5 } & Quick Ratio & 0 & 0 & 11.55 \\
\cline { 2 - 5 } & Net working Capital & 0 & 1577 & 5339 \\
\hline \multirow{2}{*}{ Debt structure } & Debt-Equity & 0 & 0 & 0.069 \\
\hline \multirow{3}{*}{ Uses of fund } & Source of fund 1(Activities contribution) & 0 & 0 & 1.4 \\
\cline { 2 - 5 } & Source of fund 2(Grants and donation) & 0 & 0 & 0.16 \\
\cline { 2 - 5 } & Use of fund 2(training) & 0 & 0 & 0.33 \\
\cline { 2 - 5 } & Use of fund(educational) & 0 & 0 & 0.0056 \\
\hline Net operating & Net Operating & 0 & 0 & 0.167 \\
\hline
\end{tabular}

Liquidity: based on the two year financial report (Company had a dormant account in 2007 so no data was available). In 2008 the company had an abbreviated account in that the financial report was not full. The company had a full financial report only in 2009), the organisation had a current ratio of 3.74 in 2008 followed immediately by a sharp rise to 15.4 in 2009 . This ratio suggests that the CIC company has the capacity to meet up with its short term debt obligation. A more rigorous test that excluded the company's stocks was conducted in the form of quick ratio and it shows a value of 11.55 in 2009. Moreover, the net working capital of the organisation further confirms the initial suspicion. The net working capital was 1577 in 2008 which was more than doubled in 2009. In spite of the data restriction, the liquidity measure suggests that the organisation have no cash flow problems.

Debt structure: the available data shows a debt to equity ratio of 0.069 in 2009 . The liabilities ratio in 2009 was relatively low compared to total assets.

Sources of funds: The level of dependence on grants and donations was at the rate of 1.4 of total expenditure in 2009. However, an alternative source of funding through the activities contribution shows a lower figure at 0.16 of the total expenditure. 
Despite the two sources of income (grants and donations and activities contribution) that the organisation had in 2009, it is still heavily reliant on grants and donations from the government.

Uses of funds: this measure revealed that the company spent $33 \%$ of the total expenditure on conference in 2009 with $16 \%$ on educational materials while less than $5 \%$ was expended on training. This implies that the company did not place as much emphasis on expenditures that was related to their primary objective.

Net operating results: The data available for the 2009 financial year showed that there was a surplus at 1.59 , suggesting that the company's total income for that year was more than the actual amount that was expended.

The results and analyses presented in the foregoing show that both organisations recognise the importance of having a sound cash management. This is in line with a research conducted by Jose et al., (2008) when they found that firms have a positive view of the monitoring cash management. The result of the interview conducted on the church also revealed that the organisation has identified the risk faced over the years in the management of cash which includes: risk of theft, misappropriation of funds and poor reconciliation. This is in line with what the Charity commission found to be potential risks for charities.

Also the strategy they have adopted to cope with financial risks relating to unavailability of funds are rescheduling of payment and negotiation with customers. This is in line with what Fairchild (2002) suggested that financial risk management activities can reduce total risk and it could be value adding especially if it reduces the cost of financial distress. Furthermore, another coping strategy which they implement to cope with income irregularities relating to having a large youth congregation is to either cancel the programme or to scale down the volume of the programme during the off peak period. Furthermore adequate provision is in place to save for raining day and as well as safeguarding of assets through insurance policies.

On the other hand, the risk which the CIC faces in the management of cash is inflation. Moreover, in terms of coping with financial risk of unavailability of funds, they are not really faced with this risk as they enjoy support from a faith based organisation. They have also been able to cope well even when funding is not regular.

In the church, planning for programmes is done through the conference planning committee (CPC) and factors like financial solvency and the target audience when planning for programmes are considered. The church has a comprehensive annual budget which is not adhere to because of inflation, interest rate and the value added tax. Moreover, if the budget is followed through, it will affect the way in which cash is disbursed for programmes not included in the budget as well as the actual programmes on the budget. The mission of the Church is always the basis for programme planning. The practice of nonadherence to annual budget is firmly supported by Hartnett (2009), who is of the view that unpredictable events may influence budgeting in NPOs. However, non-adherence to budget will cause extra expenditures to be incurred and will obviously impact on the flow of cash during the off peak periods. This could have impact on the organisation's credit worthiness. This is firmly supported by Chabotar (1989).

On the other hand, planning in the CIC is done based on the type of funds they are 
able to get. Moreover, availability of funds is the main deciding factor whenever they want to embark on projects. They don't have any comprehensive budget that they follow as most of their plans for projects are often times incorporated in the grants proposals. Budgeting can affect the availability of funds for programmes if projects are budgeted for ahead of time and support solicited from other nongovernmental sources.

From findings, the two organisations are fully aware that there are risks involved in the management of cash and they have adopted varying strategies to cope. The question that comes to mind particularly for the Church is whether outright cancellation of a programme an effective strategy to cope with income irregularities. However this strategy is also in line with what the charity commission suggests for charities on risk management. In addition, the strategy may seem perfect in the interim as the authors are of the view that it could affect their relationship with customers (Besson-Levine and Young, 2009).

\section{Conclusion and Recommendation}

This study attempted to comparatively analyse strategic financial management practices in two NPOs. The research has shown that the church is totally dependent on gifts and donations as a major source of funding and it is not financially solvent. Faith-based organisations may consider exploring other avenues for getting money like fund raising activities. This will help to ease their cash flow especially during off peak periods as well as their liquidity problems.

Furthermore, the management of religious organisations should consider adopting strategies like donor motivation to raise their income as supported by Mount (1996); Shelton and Roger(1981); Farsides (2007); Smith and McSweeny (2007) when they noted that there are certain variables like belief in the cause, joy of giving, liking to be asked, altruism, sympathy etc.that could influence donatives' behaviour.

Though not established for commercial purposes, non-profit organisations are encouraged to embark on cost control and reduction to justify their funding by financiers. This in line with the suggestion of Denison and Beard (2003) that managers should keep administration lean and build reserve funds to cushion against financial shock. Moreover, attempts should be made to address areas of value creation. This includes: redefining their mission, adopting the best practice within the organisation, invest in high impact projects, innovation and active partnering with for profit to widen their scope for social value creation. Finally, the non-profit oriented organisations need to have discussions with experts who have backgrounds related to financial management in order to discuss the management strategy for improving their financial performance.

\section{References}

1. Abraham, A. (2006) "Financial Management in the Non-profit Sector: A Mission-Based Approach to Ratio Analysis in Membership Organisations". The Journal of American Academy of Business. Vol.9,No.2, pg 212-217.

2. Allot, A., (2001), Business Basics "Cashflow Management". Chartered Institute of Management Accountants. (Online at www.cimaglobal.com retrieved on 16/08/2010)

3. Batrancea, I., Batrancea, L., Batrancea, M., Borlea, S., Ardelean, V. and Trifoi, I (2008) "The role of cash flow in the financial management of the entity". Annals of Computational Economics.Vol.1, No.36, Pages: $34-40$

4. Besson-Levine and Young, R. (2009) " Improving cash flow using credit management. The outline case". Chartered Institute of Management Accountants.(Online at:www.cimaglobal.com/.../cid_improving_c ashflow_using_credit_mgm_Apr09.pdf.pdf, 
retrieved on $2 / 11 / 2010$ )

$$
\begin{aligned}
& \text { 5. Blackbaud } \\
& \text { Management } \\
& \text { Organisations”. } \\
& \begin{array}{l}
\text { 6. (Online at } \\
\text { Not-for-Profit }
\end{array} \\
& \text { retrieved on } 05 / 04 / 2010)
\end{aligned}
$$

7. Charity facts (online at http://www.charityfacts.org/charity_facts/i ndex.html retrieved on $05 / 08 / 2010$ )

8. Cavaye, A.L.M. (1996). "Case study research: a multi-faceted research approach for IS". Information Systems Journal, Vol.6, No.3 pp.227-242.

9. Chastain C and Cianciolo (1986) "Strategies in Cash- Flow Management". Business Horizons. May/June 1986

10.Chabotar K.J (1989) " Financial Ratio Analysis Comes to Nonprofits" .The Journal of Higher Education, Vol. 60, No. 2 pp. 188208

11.Collis J and Hussey, R. (2009) "Business Research: a Practical Guide for Undergraduate and Postgraduate Students", Third edition. Palgrave Macmillan.

12.Davies, H (2000) Practical Cost-Benefit Analysis for Financial Regulators Version 1.1, Financial Services Authority Central Policy, June 2000

13.Denison, D.V., and Beard, A. (2003). "Financial Vulnerability of Charitable Organisations: Lessons from Research". Journal for Nonprofit Management, Vol7, No.1, pp23-31

14.Dropkin, M and Hayden, A (2001) "The Cash Flow Management Book for Nonprofits: A Step-by-Step Guide for Managers, Consultants, and Boards". Wiley Company

15. Eisenhardt, K.M (1989) Building theories from case study research.Academy of Management. The Academy of Management Review Vol.14, No.4, pp. 532550

16.Eisenhardt K.M (1989) "Agency theory:
An Assessment and Review". Academy of Management Review, Vol.14, No. 1, pp 57-74

17.Gunderson C (2008) "Best Practices for nonprofit budgeting and cash forecasting". Clifton Gunderson LLP, Count on Insight.

18.Gulati-Partee. G (2001)“A Primer on Non-profit Organisations". Popular Government .Summer 2001

19.Hartnett B (2009) "The Important Role of Budgeting in Nonprofits Organisations" Sobel and Co. Nonprofits and Social Services Group.

20.Hussey, J. and Hussey, R. (1997) Business Research: a Practical Guide for Undergraduate and Postgraduate Students. Basingstoke. Macmillan Business.

21.Irvine. H (2005) "Balancing money and mission in a local church budget". Accounting, Auditing and Accountability JournalVol 18 No. 2, pp. 211-237

22.Jose L., Iturralde, T. and Maseda, A (2008) "Treasury Management versus Cash Management". International Research Journal of Finance and Economics. Issue 19 pp 192-204

23.Kautz, J. (2007), "Financial management" (Online at: ww.smallbusinessnotes.com/operating/fin mgmt.html, retrieved,27/12/2010)

24.Kluvers, R. (2001)"Budgeting in catholic parishes: an exploratory study" Financial Accountability and Management, Vol. 17, No.1, pp 41-58

25.Lightbody, M (2000) "Storing and shielding: financial management behaviour in a

church organisation". Accounting, Auditing and Accountability Journal, Vol. 13 No.2, pp. 156-174.

26.Linn M (2009) “Cost-benefit analysis: a disparagement of its misuse and misexplanation"The Bottom Line: Managing Library Finances Vol. 22 No. 3, pp. 82-85

27.Linn M (2010) “Cost-benefit analysis: a 
primer "The Bottom Line: Managing Library Finances

Vol.23, No. 1, pp 31-36

28.Linn M (2009) “Cost-benefit analysis: a disparagement of its misuse and misexplanation" The Bottom Line: Managing Library Finances Vol. 22 No. 3, pp. 82-85

29.Maritz, M. (2005) "Financial management handbook series for community-based organisations". Published by the Institute for Democracy in South Africa (IDASA

30.Mount J. (1996). "Why donors give". Nonprofit Management and Leadership, Vol. 7 No.1, pp 3-14.

31.McKinney, J.B (2004) "Effective Financial Management in Public and Nonprofits agencies". Praeger Publishers

32.Mustafa, H (1994) "Conflict of Multiple Interests in Cost-Benefit Analysis" Sector Management, Vol.7 No. 3, 1994, pp. 16-26.

33. Neely A, Bourne M and Adams C (2003) "Better budgeting or beyond budgeting". Measuring business excellence. Vol.7, No. 3 pp 22-23

34.Noy E (1999) "There are profits in your management control systems "Managerial Auditing JournalVol.14, No 7, pp.363 - 368

35.Peer, M. (2008) "Financial ratios for not for profit organisations". On balance Sept/Oct 2008

36.Powell, R (1997) "Basic research methods for librarians". Third edition, Greenwood Publishing Group

37.Saunders, M., Lewis, P. and Thornhill, A. (2007) "Research Methods for Business Students". Fourth Edition. London. Financial
Times. Prentice Hall.

38.Shelton, M. and Rogers, R. (1981), 'FearArousing and Empathy-Arousing Appeals to Help: The Pathos of Persuasion, 'Journal of Applied Psychology, Vol. 11, No.4 pp. 366378

39.Smith N (2010) "Writing Cost benefit Analysis." Edited and published by Michele McDonough

40.(Online at http://www.brighthub.com/office/projectmanagement/articles/58181.aspx\#ixzz15y BNqwYs, Retrieved on 05/08/2010)

41.Smith J. R. and McSweeney, A. (2007) 'Charitable Giving: The Effectiveness of a Revised Theory of Planned Behaviour Model in Predicting Donating Intentions and Behaviour,' Journal of Community and Applied Social Psychology, Vol. 17, No. 5, pp. 363- 386

42.Sivabalan P and Brown D (2008) "To plan and control In the black; Apr 2008; Vol.78, No. 3;

pp. $65-67$

43.Waal, A. (2005) "Is your organisation ready for beyond budgeting?"Measuring Business Excellence Vol 9 No. 2, pg 56 -67

44.Weerawardena, J, McDonald R.E and Mort G.S (2009) "Sustainability of Nonprofit organisations: An empirical investigation". Journal of World Business, $\mathrm{xxx}(2009) \mathrm{xxx}-\mathrm{xxx}$

45.Zietlow. J, Hankin. J. and Seidner A (2007) "Financial Management for Nonprofit Organisations: Policies and Practices, John Wiley and Sons Inc. 